\title{
Therapeutic adherence in patients with systemic lupus erythematosus: a cross-sectional study
}

\author{
LUCIA MAZUR-NICORICI, VICTORIA SADOVICI-BOBEICA, MARIA GARABAJIU, MINODORA MAZUR \\ Department of Internal Medicine, "Nicolae Testemițanu" State University of Medicine and Pharmacy, \\ Bd. Ştefan cel Mare şi Sfânt, 165, MD-2004, Chisinau, Republic of Moldova
}

\begin{abstract}
Introduction. The aim of the research was the study of the adherence to treatment in patients with systemic lupus erythematosus.

Methods. Cross-sectional study including 132 consecutive patients with systemic lupus erythematosus (SLICC, 2012 classification criteria). We collected clinical and socio-demographic data, socio-economic status; we assessed SLEDAI-2k disease activity, and estimated the adherence to treatment by Morisky questionnaire.

Results. Our results demonstrated that low adherence to treatment in patients with systemic lupus erythematosus was in only $11.36 \%$ of patients, while $43.18 \%$ and $45.46 \%$ of the patients were scored as moderate and high adherence, respectively. A moderate/high adherence to treatment was associated to a high level of education $(\mathrm{r}=-0.51, \mathrm{p}<0.05,95 \% \mathrm{CI}=-0.25$ to -0.66$)$, low disease activity $(\mathrm{r}=0.38, \mathrm{p}<0.05,95 \% \mathrm{CI}=0.25$ to 0.53$)$ and low indices of physician global assessment $(\mathrm{r}=-0.31, \mathrm{p}<0.05,95 \% \mathrm{CI}=-0.23$ to -0.71$)$. The sub-analysis of the adherence to each drug demonstrated that the highest adherence was to treatment with glucocorticosteroids $-92.85 \%$, followed by hydroxychloroquine and aspirin $-92.15 \%$ and $89.79 \%$, respectively.

Conclusion. In our cohort, the adherence to treatment was high in $45.46 \%$, moderate in $43.18 \%$ and low in only $11.36 \%$ cases. High adherence to treatment was associated to low disease activity. The adherence was positively influenced by the age at the onset of the disease and a high educational level.
\end{abstract}

Keywords: adherence, compliance, systemic lupus erythematosus, treatment, Morisky.

\section{INTRODUCTION}

Adherence to treatment is defined as the conviction of each patient to follow the physician's recommendations regarding diet, exercise and medication agreed upon by physician and patient $[1,2]$. Current scientific evidence regarding medication itself presupposes the establishment of a drug administration plan, dose, frequency and duration of the treatment. Research on chronic diseases, including rheumatoid arthritis and lupus, has found that non-adherence to treatment is multifactorial and may be intentional and unintended. It is stipulated in the literature that adequate treatment in systemic lupus erythematosus (SLE) improves consequences of the disease, increasing life expectancy. Therewith, the findings of the research showed variable rates of non-adherence among lupus patients, ranging from 3 to $76 \%$, which assume that disease can and must be controlled on compliance to treatment by different methods because the treatment is prescribed in the long term, often throughout life, in various regimes and associations [3]. Patients are afraid of the side effects of treatment, and it persists the lack of communication with health care providers - doctor, nurse or pharmacist. Nonadherence in rheumatologic diseases, including lupus, can contribute to unwanted consequences, both immediate and delayed, but also increases costs due to disease or treatment complications, as well as comorbidities. The clinical impact of nonadherence or low adherence to the indicated treatment conjugates to undesirable consequences of the disease by progression of the renal pathology, exacerbating or increasing the activity of the disease. Totalizing all the data from the published literature we have selected the causes of non-adherence to treatment, which are the duration of the disease, age, educational level, the unemployed or household status, the high costs of treatment and investigations, the difficulty of completing numerous forms for pharmacies, other healthcare providers (neurologist, physiotherapist, physical therapist, etc.), low self-efficacy, depression, low social support, inconvenient patient/doctor relationship, or distrust in doctor/public health system - barriers from health care system, the 
excessive use of alcohol, but also the irresponsibility of administering medication by avoiding taking tablets [1-5].

Measurement of adherence. Several methods have been proposed and used to assess nonadherence to treatment by direct or indirect methods. Indirect methods of evaluating non-adherent treatment is tablet's counting. In this case, the administration of the drugs at home could not be assessed. A method of assessing adherence to treatment is selfreporting, which involves administering the treatment monitoring agenda, self-administered and autoreported questionnaires. The clinical importance of low/non-adherence was the increase in the number of undesirable consequences of the disease (eg, development of renal failure, osteoporosis, fatigue). Morisky D et al. developed the Morisky Medication Adherence Scale (MMAS) with 8 elements (MMAS-8) in 2008, based on the Medication Adherence Questionnaire (MAQ) [6]. The questionnaire's first seven elements have yes/no answers, while the last element has 5 answers (Likert scale). The Moriski questionnaire has a sensitivity of $93 \%$ and a specificity of $53 \%$. It has been validated in "low-income minority patients treated for high blood pressure who seek routine care in a clinic"; it also has been recently validated in Greece with the participation of D. Morisky [7]. In addition, MMAS-8 has been validated with remarkable validity and reliability in patients with other chronic diseases. As a result, it is the most accepted measure of self-reporting for medication compliance.

Latest studies show different degrees of adherence to drugs in SLE patients, thus the compliance to glucorticosteroids (GCS) in some studies is lower than to HCQ, but overall moderate/high adherence in lupus is about $80 \%$. The results of recent studies suggest that non-adherence is determined by the low level of education, loneliness, excess of alcohol use, frictional or involuntary unemployment $[4,5]$.

\section{MATERIALS AND METHODS}

The objective of the study was to evaluate the adherence to treatment and to analyse its clinical and socio-demographic impact on patients with SLE.

Clinical and socio-demographic data were collected, according to SLICC, 2012, classification criteria, SLEDAI-2k disease activity assessment, socio-economic status (SES), and the estimation of adherence to treatment by Morisky questionnaire. Assessment of compliance to treatment was performed on each group of remedies separately (GCS, immuno- suppressants, Hydroxychloroquine (HCQ), nonsteroidal anti-inflammatory drugs (RANS), lowdose aspirin, heparin, Calcium, and others.

According to Morisky recommendations, subjects were divided into 3 study groups: high adherence -0 points, moderate $-1-2$ points and low adherence from 3 to 8 points. Regarding the socio-economic status assessment - SES, we have used the Kuppuswamy Index as an important tool, used in hospitals and community based research, which was developed in 1976 in India and has been used successfully in the SES evaluation [8]. The Kuppuswamy Socio-Economic Status Scale includes three areas of evaluation - A. Education of the head of the family in points, B. Occupation of the head of the family, points and C. Total monthly income of the family from all sources. The total score versus the socio-economic class in SESare upper, upper middle, middle/lower middle, lower/ upper lower, lower.

\section{Statistical analysis}

The statistical analysis was made in Microsift Excel 2010 and MedCalc statistical software, version 12.7.0. The results were presented as mean values \pm SD for normal distribution data and medians with range for skewed data. The statistical difference was calculated using t-Student criteria, the 95\% CI were presented. The correlations were calculated by Pearson coefficient.

\section{Ethical approval}

The Ethic Committee of the State University of Medicine and Pharmacy "Nicolae Testemițanu" on 08 June 2017, session number 78, approved the study. The study was conducted according to the ethical standards in the Helsinki Declaration of 1975, as revised in 2000 (5), as well as the national law.

\section{RESULTS}

In the performed study there were included 132 consecutive patients with SLE, admitted to the Rheumatology Department of the Institute of Cardiology from January 2015 to June 2017. All patients signed the informed consent form.

The analysis of the patient's data (Table 1) demonstrates the predominance of female gender (97.72\%) and the rural place of residence (67.42\%), medical insurance was present in $78.78 \%$ of patients. 
The average education level of patients was about 13 years of study, with variation intervals (v.i.) of 9 to 22 years. From the point of view of the socioeconomic status, education varied from upper secondary ( 9 years) in $9.09 \%$ of patients, to higher education completed with masters studies (43.18\%). The mean age at onset was 33 years, the duration of the disease was about 10 years, and the time from the first symptoms to diagnosis was approximately one year with variations from 2 weeks to 35 months.

Table 1

General characteristics of the patients from the study group (No. = 132)

\begin{tabular}{|c|c|c|}
\hline Parameters & No. of patients & $\%$ \\
\hline \multicolumn{3}{|l|}{ Gender } \\
\hline Women & 129 & 97.72 \\
\hline Men & 3 & 2.27 \\
\hline \multicolumn{3}{|l|}{ Place of residence } \\
\hline Rural & 89 & 67.42 \\
\hline Urban & 43 & 32.57 \\
\hline \multicolumn{3}{|l|}{ Medical insurance } \\
\hline Yes & 104 & 78.78 \\
\hline No & 28 & 21.21 \\
\hline Disability & 57 & 43.18 \\
\hline \multicolumn{3}{|l|}{ Professional status } \\
\hline Full time employment & 39 & 29.54 \\
\hline Part-time employment & 30 & 22.72 \\
\hline Unemployment & 24 & 18.18 \\
\hline Retired persons & 12 & 9.09 \\
\hline Household status & 27 & 20.45 \\
\hline \multicolumn{3}{|l|}{ Number of criteria at onset } \\
\hline$\geq 10$ & 6 & 4.54 \\
\hline $6-9$ & 84 & 63.63 \\
\hline $4-5$ & 42 & 31.81 \\
\hline Parameters & Mean number \pm SD & range \\
\hline Age at the study entry, years & $44.12 \pm 13.49$ & $18-68$ \\
\hline Education (Years) $<9$ & $13.26 \pm 3.09$ & $9-21$ \\
\hline $10-13$ & No 12 & $9.09 \%$ \\
\hline \multirow[t]{2}{*}{$>14$} & No 63 & $47.72 \%$ \\
\hline & No 57 & $43.18 \%$ \\
\hline Age at onset & $33.63 \pm 11.90$ & $13-59$ \\
\hline Disease duration, months & $120.07 \pm 126.08$ & $1-442$ \\
\hline $\begin{array}{l}\text { T-T0 the time from disease onset to } \\
\text { the diagnosis, months }\end{array}$ & $12.61 \pm 18.02$ & $0.5-38$ \\
\hline
\end{tabular}

We analysed disease activity in the patients included in the study. The activity of our patients in the research group falls into three groups - highactivity lupus, low disease status and remission (Figure 1).

The median (range) of the disease activity by SLEDAI-2K was $6(0-20)$ points. According to the definition, $6(4.45 \%)$ patients were in remission with the SLEDAI score - 0. Low Lupus Disease Activity Status (LLDAS) met 75 (56.81\%) patients, where SLEDAI $\geq 4$ points without significant organic damage, $\mathrm{PGA} \leq 1$ (0-3), with no symptoms of disease exacerbation and CGS $\leq 7.5 \mathrm{mg}$ /day. High disease activity by SLEDAI-2K, determined by presence of 5 or more points, was identified in 51 $(38.63 \%)$ patients, which indicates the need for more active therapy and encouragement for the patient to administer the treatment indicated by the doctor.
Hereinafter, we analysed the adherence to treatment assessed by the self-administered tool the Morisky- 8 item scale, and the answers were divided in: high adherence - pointed by 0 , moderate adherence to treatment $1-2$ points and low 3 to 8 points. The results from Table 2 show that high adherence was present in $60(45.46 \%)$ patients, and $15(11.36 \%)$ of the patients were scored as low adherence.

We analysed the adherence to each drug (Table 3), and it was demonstrated that the highest adherence was to GCS treatment $-92.85 \%$, followed by hydroxychloroquine and low-dose aspirin 92.15 and $90.90 \%$, respectively.

We have found that the compliance to immunosuppressive therapy was low, probably due to the poor medical explanation, as well as the lack of these drugs in pharmacies (Azathioprine) or their high cost (Mycophenolat Mofetil). Biological 
treatment was indicated to 14 patients, of whom 3 refused, and 11 received it.

From the data presented in Table 4, by analysing each individual index, one can see that in case of disease onset in younger age, the adherence is higher, but with disease duration the compliance to the treatment decreases. The higher educational level increases the compliance to the treatment. According to the obtained results, we established a moderate correlation with the activity of the disease assessed by SLEDAI and SLAM and the level of ANA. Regarding the number of the onset criteria, we established a moderate positive correlation with adherence by Morisky. Our data did not reveal the correlation with such indices as age at the time of research, damage index or increased levels of antidsDNA, decreased $\mathrm{C} 3$ and $\mathrm{C} 4$ complement levels.

In the following, we examined the adherence by the Morisky scale. Data analysis according to the scale showed that the median (range) therapeutic adherence in SLE patients was $2(0-6)$, considered as moderate. The number of patients with low adherence was 15 , representing $11.36 \%$ of the study group. The group of patients with moderate and high adherence was similar, $43.18 \%$ and $45.46 \%$, respectively.

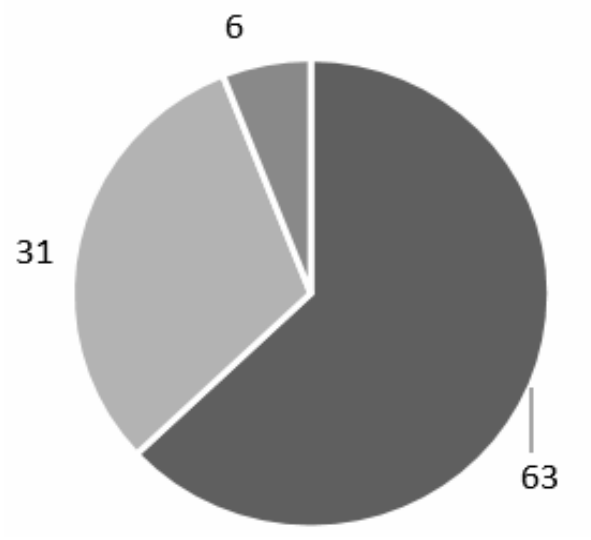

\section{- High disease activity}

Low disease
activity

- Remission

Figure 1. Variants of disease activity in SLE.

Table 2

Adherence to treatment in patients with SLE $($ No. $=132)$

\begin{tabular}{lcc}
\hline \multicolumn{1}{c}{ Parameters } & No. of patients & \% \\
\hline Morisky Adherence scale, points & 60 & 45,46 \\
High -0 & 57 & 43,18 \\
Moderate $-1-2$ & 15 & 11,36 \\
Low $-3-8$ & & \\
\hline
\end{tabular}

Table 3

Indices of medication adherence in patients with SLE

\begin{tabular}{lccc}
\hline \multicolumn{1}{c}{ Medication } & $\begin{array}{c}\text { No. of patients } \\
\text { requiring the } \\
\text { treatment }\end{array}$ & $\begin{array}{c}\text { No. of patients } \\
\text { taking the } \\
\text { treatment }\end{array}$ & \% \\
\hline GCS & 126 & 117 & 92.85 \\
Hydroxychloroquine & 102 & 94 & 92.15 \\
Azathioprine/Cyclophosphamide & 59 & 9 & 15.25 \\
Methotrexate & 5 & 2 & 40.00 \\
Mycophenolate Mofetil & 9 & 2 & 22.22 \\
Low dose Aspirin & 121 & 110 & 90.90 \\
Heparine & 98 & 88 & 89.79 \\
Non-steroidal anti-inflammatory drugs & 56 & 41 & 73.21 \\
Calcium & 98 & 75 & 76.53 \\
Bisphosphonates & 82 & 41 & 50.00 \\
\hline
\end{tabular}


Table 4

Correlation of adherence with SLE indices

\begin{tabular}{lccc}
\hline \multicolumn{1}{c}{ Parameter } & r & p & $\mathbf{9 5 \%}$ CI \\
\hline Age at onset & 0.36 & 0.02 & 0.24 to 0.47 \\
\hline Age at the study entry & 0.13 & 0.13 & 0.17 to 0.40 \\
\hline Disease duration, month & 0.31 & 0.21 & 0.29 to 0.53 \\
\hline Years of studies $\geq 12$ & -0.51 & 0.05 & -0.25 to -0.66 \\
\hline PGA (0-3) & -0.31 & 0.11 & -0.23 to -0.71 \\
\hline No. of criteria at onset & 0.30 & 0.0003 & 0.27 to 0.41 \\
\hline Disease activity & & & \\
SLEDAI-2k & 0.38 & 0.04 & 0.25 to 0.53 \\
SLAM & 0.37 & 0.04 & 0,19 to 0.60 \\
\hline Damage Index SLICC/ACR & 0.01 & 0.96 & -0.19 to 0.23 \\
\hline ANA & 0.34 & 0.0048 & 0.25 to 0.74 \\
\hline Anti dsDNA & 0.01 & 0.97 & -0.23 to 0.56 \\
\hline C3 & 0.51 & 0.41 & 0.20 to 0.71 \\
\hline C4 & 0.42 & 0.29 & 0.29 to 0.60 \\
\hline
\end{tabular}

\section{DISCUSSION}

Since the time of Hippocrates, it has been observed that the patient's healing health requires respect for the regimen prescribed by the physician [9]. The term adherence is the attitude of the patient towards the therapeutic scheme that refers to both observance of the long-term medication and lifestyle changes. Literature data denotes that the lack of compliance or non-compliance is the main cause of therapeutic failure, simultaneously the costs of non-compliance of patients with chronic diseases are as high as $\$ 13.35$ billion dollars annually in the US alone [10].

Adherence to the treatment indicated in SLE remains high, but differs from drug to drug. Thus, the group led by Koneru, 2008 found adherence to the general medication of $80 \%$, when to GCS was $61 \%$, much lower than adherence to GCS among the patients included in our study, who demonstrated adherence to GCS of $92.85 \%$ [11]. We also compared HCQ compliance in our patients who showed the adherence of $92.15 \%$ versus $49 \%$ in the study conducted by Koneru. Comparison of data from the two studies on immunosuppressant treatment has shown that patient's adherence in our study is relatively low, constituting $15.25 v s .57 \%$ of cases. In the newer works, the adherence rate was variable, between $3-76 \%$ while in patients of our study it was from 15.25 to $92.85 \%$ [3]. Non-adherence in our study constituted $7.29 \%$ versus $64 \%$ in the recently completed study, led by Prados-Moreno, 2017, and in our opinion it is very low [4]. Sueldo reported at American College of Rheumatology Annual Congress, 2016 an overall adherence to treatment of $63 \%$, commenting that the adherence was good and correlated with the educational level and polypragmazia, otherwise the impact of such indices as age, duration of illness, socio-economic status and disease activity was not found [12].

It was established that high adherence to treatment provides benefits to the patient with chronic disease, including lupus. Patients with a positive attitude to accept the limitations imposed by the disease, promoting protective factors and omitting risk factors in installing non-adherence to medical and alternative therapy, tolerate illness and its consequences more easily. We have determined that lupus patients have adopted a lifestyle according to the disease, through diet, aerobic exercise, control of stress and overwork, help the doctor with medical-social assistance by early detection of complications of the disease and adverse effects of drugs, recognizing unwanted consequences of disease and co-morbidities at the time of their installation. In the data from our study, adherence to treatment correlated negatively with PGA. So, the higher the adherence to treatment, the lower the activity of the disease, and the overall condition of the patient is better. The number of the onset criteria showed to be a negative factor for the good adherence to treatment, that can be explained by patient's bad condition at the onset, which improved and led to patient's assumption that he has recovered, and the compliance to the treatment at the moment it is reduced. We evaluated the adherence to treatment in correlation with disease activity and years of study, finding a good correlation. According to the obtained results, we did not find a correlation or statistically significant data between the adherence and the damage index and the anti-dsDNA level. 


\section{CONCLUSION}

In our cohort, the adherence to treatment was high in $45.46 \%$, moderate in $43.18 \%$ and low in only $11.36 \%$ cases. High adherence to treatment was associated to low disease activity. The adherence was positively influenced by the age at the onset of the disease and a high educational level.

Conflict of Interest disclosure: The authors declare that there are not conflicts of interest.

Introducere. Scopul studiului efectuat a fost aprecierea aderenței la tratament la pacienții cu lupus eritematos sistemic.

Metode. Am efectuat studiul transversal pe lotul de 132 pacienți consecutivi cu diagnosticul de lupus eritematos sistemic, prin respectarea criteriilor de clasificare SLICC, 2012. Am colectat datele socio-demografice, socio-economice a pacienților, am apreciat activitatea maladiei prin indicele SLEDAI-2K şi am evaluat aderența la tratament conform chestionarului autoadministrat Morisky.

Rezultate. Rezultatele studiului nostru au demonstrat că complianța joasă la tratament a fost doar la $11.36 \%$ din pacienți, pe când grupurile cu aderența moderată şi înaltă au constituit $43.18 \%$ şi, respectiv, $45.46 \%$ de pacienți. Aderența moderată/înaltă la tratament a fost asociată cu nivelul înalt de educație $(r=-0.51$, $p<0.05,95 \% C I=-0.25-(-0.66))$, activitate joasă a maladiei $(r=0.38, p<0.05$, $95 \% C I=0.25-0.53)$ şi indicele de evaluarea globală a pacientului de către medic $(r=-0.31, p<0.05,95 \% C I=-0.23 t-(-0.71))$. Analiza complianței la fiecare medicament aparte a constat în aderența la tratament $\mathrm{cu}$ glucocorticosteroizi - 92.85\%, urmată de hidroxiclorochină şi aspirină - 92.15\% şi, respectiv, $89.79 \%$.

Concluzie. In studiul prezent, aderența la tratament a fost înaltă în $45.46 \%$, medie în $43.18 \%$ şi joasă doar în $11.36 \%$ de cazuri. Aderența înaltă la tratament a fost asociată cu activitatea joasă a maladiei. Aderența a fost influențată pozitiv de vârstă la momentul stabilirii diagnosticului şi nivelul educațional înalt.

Correspondence to: Victoria Sadovici-Bobeica, M.D, Department of Internal Medicine,

"Nicolae Testemițanu" State University of Medicine and Pharmacy,

Bd. Ştefan cel Mare şi Sfânt, 165, MD-2004, Chişinau, Republic of Moldova

Tel. (+373) 60344394, Fax: (+373) 22242344

E-mail: victoriasadovici@gmail.com

\section{REFERENCES}

1. FARINHA F., FREITAS F., ÁGUEDA A., CUNHA I., BARCELOS A. Concerns of patients with systemic lupus erythematosus and adherence to therapy - a qualitative study. Patient Preference and Adherence. 2017; 11:1213-1219.

2. CHAMBERS SA., ALLEN E, RAHMAN A., ISENBERG D. Damage and mortality in a group of British patients with systemic lupus erythematosus followed up for over 10 years. Rheumatology (Oxford). 2009; 48(6):673-675.

3. COSTEDOAT-CHALUMEAU N., POUCHOT J., GUETTROT-IMBERT G., LE GUERN V., LEROUX G., MARRA D. Adherence to treatment in systemic lupus erythematosus patients. Best Pract Res Clin Rheumatol. 2013; 27(3):329-340.

4. ACHAVAL S., SUAREZ-ALMAZOR M. Treatment adherence to disease-modifying antirheumatic drugs in patients with rheumatoid arthritis and systemic lupus erythematosus. Int J Clin Rheumtol. 2010; 5(3): 313-326.

5. VERMEIRE E., HEARNSHAW H., VAN ROYEN P., DENEKENS J. Patient adherence to treatment: three decades of research. A comprehensive review. J Clin Pharm Ther. 2001; 26(5):331-342.

6. Oliviera-filho a., morisky d., neves s., costa f., lyra d. The 8-item Morisky medication Adherence Scale: validation of a Brazilian-Portuguese version in hypertensive adults. Res Social adm Pharm.2014; 10(3):554-61.

7. PLAKAS S.,MASTRIGIANNIS D., MANTZOROU M., ADAMAKIDOU T., FOUKA G., BOUZIOU A., et al. Validation of the 8-Item Morisky medication adherence scale in chronically ill ambulatory patients in rural Greece. Open Journal of Nursing, 2016; 6:158-169 
8. GADHAVE S, NAGARKAR A. Kuppuswamy scale for measuring socio-economic status: revised monthly income figures for 2015. Indian J Pediatr. 2015; 82(12):1175-6.

9. SCHECHTMAN KB. Patient Compliance. In: Encyclopedia of Biopharmaceutical Statistics, Shein-Chung Chow, North Carolina, 2003: 712/717.

10. MARTIN LR, WILLIAMS SL, HASKARD KB, ROBIN DIMATTEO M. The challenge of patient adherence. Ther Clin Risk Manag. 2005; 1(3): 189-199.

11. KONERU S., SHISHOV M., WARE A., FARHEY Y., MONGEY AB., GRAHAM TB., et al. Effectively measuring adherence to medications for systemic lupus erythematosus in a clinical setting. Arthritis Rheum. 2007; 57(6):1000-1006.

12. SUELDO R., BERTOLACCINI MC., MALDONADO R., ROMERO J., GONZALEZ LUCERO L., ESCOBARET MM., et al. Adherence to treatment and social, educational levels in patients with systemic lupus erythematosus. Arthritis Rheumatol. 2016; 68 (suppl 10).

Received January 15, 2018 